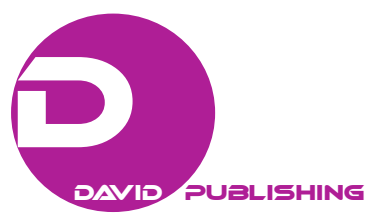

\title{
Aristotle and Hollywood: Dramatic Structure From Ancient Greece to Avatar \& Beyond
}

\author{
Andrew Horton \\ The University of Oklahoma, Norman, Oklahoma
}

\begin{abstract}
It is fascinating to realize that even while Hollywood continually comes up with incredible special effects in films such as Avatar (2009), the basic structure and development closely "follows" the guidelines for drama and storytelling laid out by Aristotle in his The Poetics, written several thousand years ago. We are specifically speaking of three act (beginning, middle, and ending) structure, focusing more on plot than character, and the need for a final resolution (catharsis). But throughout literary and cinematic history, not everyone has followed these rules. Ironically, we take a close look at the award-winning Greek director Theo Angelopoulos' Ulysse's Gaze (1995) staring Harvey Keitel, as an example of a very non-Aristotelian approach to filmmaking and storytelling. Angelopoulos' film is character rather than plot centered on the Harvey Keitel figure and the journey of the narrative can be broken down to between 8-10 acts, depending how you describe them. We discuss many of the standard American "how to write screenplay book" authors such as Syd Field, while bringing a variety of authors such as Lajos Egri (The Art of Dramatic Writing) who criticize both Aristotle's Poetics and the way it has been interpreted for centuries especially in Hollywood. We conclude that there is a middle ground as well, for while Casablanca (1942) has a clear three act structure, it does not give us a happy romantic "Hollywood" ending/resolution as Rick insists that Lisa leave with her husband.
\end{abstract}

Keywords: Aristotle's Poetics, Hollywood, narrative structure, plot vs character

\section{Introduction}

Ask anyone what is the structure of so many Hollywood films over the years and the answer comes down to the film needing a three act structure of beginning and middle and ending and with an ending that is a resolution of the major conflicts presented. Add also that traditionally, Hollywood films have emphasized plot (action) over character development as the main focus. But it is definitely helpful to realize that this so-called Hollywood approach is actually closely derived from Aristotle's definitions of story, structure and drama in Poetics written several thousand years ago. That said, we need to be aware that many filmmakers have their own approaches to narrative that differ quite widely from Aristotle's viewpoint.

Men are better or worse, according to their moral bent; but they become happy or miserable according to their actual deeds. (Aristotle, 1947, p. 24)

What do these two stories have in common?

Firstly, It is the year 2154 in outer space as we watch a paraplegic American soldier who is supposed to be

Andrew Horton, The Jeanne H Smith Professor of Film \& Media Studies, The University of Oklahoma. 
helping the US army defeat an indigenous blue skinned population on the planet Pandora for economic reasons. But instead of carrying out his assigned mission, he falls in love with a blue skinned native young woman and dedicates himself to driving the US army off of Pandora.

In our second story, a Greek filmmaker who has been away from Greece for decades returns and goes on a search for the first film ever made in the Balkans, a journey taking him through Greece, Albania, the Former Yugoslav Republic of Macedonia, Rumania, Serbia, and Bosnia while the Bosnian war is taking place.

Both stories are feature films-James Cameron's Avatar (2009) and Theo Angelopoulos' Ulysses' Gaze (1995) - and both depict characters dealing with wars taking place, but beyond that they belong to quite different narrative traditions. Our point will be that Avatar is clearly a strong plot and special effects driven Hollywood film that reflects basic "rules" of drama that were written up by Aristotle several thousand years ago. And in contrast, while Theo Angelopoulos is certainly a Greek director, his films like many independent and "non-Hollywood" movies, do not follow the so-called "rules" of drama found in Aristotle's writings.

Let us thus tune in to ancient Athens and modern Los Angeles and beyond! More specifically, any interest in the intersection of Greece and Hollywood has to take into account the long and varied influence of Aristotle on the art and craft of American screenwriting, in both a positive and negative sense, which has particularly occurred since the beginning of the "Sound Era" when cinematic storytelling more strongly crossed paths with theatrical playwriting.

Of course it is not likely that Charlie Chaplin, Buster Keaton, D.W Griffith or even Frank Capra ever opened Aristotle's Poetics. But certainly for at least during the past fifty years or more as screenwriting has become a taught course and craft with a multitude of How To Write a Screenplay books having appeared, Aristotle's concepts — or oversimplified versions of them — have had a profound influence.

To be specific, let's start with what Hollywood films, "classical” (1920s-50's) to contemporary 3-D digital animation have offered cinema audiences around the world. As Kristin Thompson notes in her fine study, Story Telling in the New Hollywood, "The most basic principle of the Hollywood cinema is that a narrative should consist of a chain of causes and effects that is easy for the spectator to follow" (p. 10). And what does this have to do with Aristotle's influence? A lot! Simply put, as the much respected UCLA screenwriting Professor, Hunter (1993) has noted in his text, Lew Hunter's Screenriting 434:

Now is the time to begin talking about Aristotle's two thousand-year-old "beginning-middle-end" structure. Aristotle was the first to put the storyteller's trade tricks down on paper. The beginning-middle-end concept is in Plato's Republic, but the elaboration of this insight you will find in Aristotle's Poetics. (p. 20)

Hunter, with whom I am proud to say I have co-taught a screenwriting seminar in Greece, goes on to insure Aristotle's descendents will receive handsome royalties by saying:

For more demystification, buy this slim volume, read it twice, then pick it up every three or four years and read it during your screenwriting career. Those are the few rules we have and need. (Hunter, 1993, p. 20)

We can be even more precise in how Aristotle's Poetics has been "simplified" by Hollywood writers, producers and Studio Chiefs, to emphasize (1) a three act structure (beginning, middle, and ending), (2) the focusing on plot over character in terms of primary focus, and (3) the need for a final "catharsis" (resolution). Avatar, like most of Hollywood's productions, certainly can be called by these formulas, "Aristotelian". We track a beginning (Act 1) while we get to see Jack Sully (Sam Worthington) trying to adjust to the US Army's 
mission on the planet Pandora to protect the minerals Earth needs to take from the planet. The "middle" (Act 2) occurs as Jack meets and falls in love with a Pandoran native woman, Neytiri (Zoe Saldana) and gets to know her Na'vi culture, and the "ending" (Act 3) becomes Jack's decision to fight with Neytiri and her people to push the Americans out of Pandora, and love and war succeed at last for Jack and Neytiri and her people.

Theo Angelopoulos has a deep fascination with Greek history, myth, and culture in his films as I have written about in The Films of Theo Angelopoulos: A Cinema of Contemplation. But while being a great admirer of 50's Hollywood cinema, especially musicals, he has purposely taken his own approach to story, plot, character, and resolution. In Ulysses' Gaze, Harvey Keitel plays the Greek film director named "A" who is on his journey to find the first film made in the Balkans. Yet instead of Aristotle's and Hollywood's three acts, this "road movie" or modern odyssey, can be broken down into 8-10 acts, depending on how you wish to identify them. And even with flashbacks into A's earlier life in Rumania, for instance, we, the viewers, are not offered the clear plot points and development of character that Kristin Thompson comments strong Hollywood films strive to offer.

Angelopoulos' depiction of character is, in fact, in contradiction with over two thousand years of character presentation and development in Western theater and literature. He is very interested how history and myth cross paths with individual destinies often combining both in single shots, but we look in vain for a simple or direct psychological character development. As I have written in my study of his films:

Hollywood's demand for "strong character" is actually in direct line with Aristotle's call for clear motivation and cause-and-effect depiction of inner struggle centered on given conflicts that must be faced and resolved. (Horton, 1997, p. 10)

The author have purposely chosen a Greek filmmaker here to suggest not everyone follows Aristotle's Poetics or Hollywood's basic formulas. But clearly in discussing Aristotle and cinema, we could mention many independent American and also foreign filmmakers who take non-Aristotelian routes to story, character, and endings that may remain "open" rather than resolved. I do wish to explore this territory as well, yet let us first return to Aristotle and his Hollywood legacy.

Certainly one of the most influential screenwriting texts that reflect these Aristotelian concepts is Syd Field's Screenplay: The Foundations of Screenwriting. As early on in the text as page 8 describes a script as not only having three acts, but identifies that Act I is the "beginning" and should end on page 30, Act II is the "middle" and should end on page 90, and Act III is the "end" and should finish by page 120 with a "resolution" (thus a catharsis). Using Roman Polanski's Chinatown (1974), as an example, Field uses his paradigm to explain that Act I ends when detective Jake Gittes (Jack Nicholson) must find out if Mrs Mulwray (Faye Dunaway) is the real Mrs Mulwray who has hired him concerning her husband's affair and murder. Act II is the "conflict" section, as Field (1982) explains:

The second act deals with Jack Nicholson coming into conflict with those forces who do not want him to find out who is responsible for the murder of Mulwray. (p. 10)

Finally, Act III, Fields comments, for this film and every film, must lead to a "strong ending" in order to make the film "comprehensible and complete" (p. 10). "The days of ambiguous endings are over", he concludes (p. 10) in the spirit of Aristophanes' emphasis on "catharsis", or a "cleansing" of powerful emotions that have been pulled forth by the drama. 
Aristotle does clearly emphasize the importance of plot over character, a point that Hollywood over the years has often carried out in exaggerated form so that we may often get almost no character development. In the Poetics, Aristotle comments, "The plot is the first consideration, and, as it were, the soul of the tragedy. Character holds the second place" (Egri, 1960, p. 92). And from Ancient Athens down to the latest Los Angeles studio executive office, plot as the first consideration has certainly topped many Studio lists-along with special effects—-for what kinds of films have been "green lighted" to be made.

Yet the "dangers" and limitations of Aristotle's observations must be observed as well. Lajos Egri has also strongly influenced those studying the writing of scripts in his 1946 work that covers stage drama primarily in The Art of Dramatic Writing in which he notes, "Aristotle denied the importance of character and his influence persists today" (p. xiv). Egri points out that Aristotle's ranking of plot over character development has had a negative effect on centuries of critics and writers since then to the degree that, "ninety-nine percent of the writings on this issue are confused and barely understandable" (p. 93). He goes further in pointing out Aristotle's analysis of tragedies is in many ways based in a belief of Fate being in control. As Egri (1960) notes:

The Greek plays that have come down to us boast many extraordinary characters which disprove the Aristotelian contention. If character were subsidiary to action, Agamemnon would not have died by the hand of Clytemnestra. (p. 97)

No one can dispute that there is much to be learned from Aristotle's observations on the nature of poetry, epic, and drama, especially tragedy, as put forth in The Poetics. And yet it is also fair to say that Aristotle himself was not a poet or playwright and that many of his observations such as the importance of plot over character or tragedy as more important than comedy, can be called into question in the same way that many of the authors who have written How To Write a Screenplay books have never had scripts written, sold, and made into films! Author John Truby (2007) puts this well in The Anatomy of Story when he comments:

Terms like "rising action", "climax", "progressive complication", and "dénouement", terms that go back as far as Aristotle, are so broad and theoretical as to be almost meaningless. Let's be honest: they have no practical value for storytellers. (p. 5)

Truby is helpful in suggesting how easy it is to miss the heart of good story telling, whether on stage or on screen, when trying to overanalyze and at the same time oversimplify the nature of story telling itself.

Even Aristotle, I feel, cannot be categorized as only feeling plot rules over character, for as the opening quote from The Poetics suggests, he understood that "action" comes from character. Thus modern authors writing about storytelling and screenwriting who emphasize structure and plot over character, including Chrtistopher Volger in The Writer's Journey: Mythic Structure for Writers, are actually misrepresenting both Aristotle and lasting storytelling itself. Aristotle even comments in The Poetics that, "the works of most of the modern tragic poets, from the time of Euripides on, are lacking in the element of character" (p. 24, italic emphasis my own).

A danger for writers always throughout history has been trying to dictate or limit creativity and storytelling to certain formulas when we are all aware that many great works don't follow such "rules". French director Jean-Luc Godard, for instance, put it well when he said, "A film should have a beginning, middle, and end, but not necessarily in that order" (Horton, 1999, p. 95). And Kazakh filmmaker Rachid Nougmanov takes on the whole notion of three acts as emphasized by Aristotle and contemporary Hollywood script book authors like Syd Field, exploring how we could more precisely talk about five act structure in Chinatown and almost all films (Horton, 2004, pp. 141-151). 
Nougmanov's conclusion is a valid one for all filmmakers and screenwriters in terms of how "religiously" one must follow Aristotle or anyone's rules of storytelling when he notes, "And what if you want to make a more personal, art house or avant-garde film? Still learn the rules - and then break them with knowledge" (Horton, 2004, p. 151).

Put simply, most Hollywood films over the years could quite easily fit Aristotle's and authors such as Syd Field's rules of three act structure with plot driven action and with a clear resolution (catharsis) in the ending from The Wizard of $\mathrm{Oz}$, Gone With the Wind, Psycho and Lawrence of Arabia, down to Star Wars, E.T., Batman, Lord of the Rings, and Shrek 1-4. Yet it is clear that Aristotle's and Hollywood's "classical" formulas were not and are not the goals of filmmakers making films such as Andy Warhol's Empire (1964), a single shot of the Empire State Building from early evening till 3 am, Monty Python's comic surrealism in The Life of Brian (1979), or even a recent film such as Hollywood financed and produced Inception (2010), written and directed by Christopher Nolan and starring Leonardo DiCaprio and Ellen Page. What if it were possible for Aristotle to return and watch a film like Inception and then respond to it! In all fairness, I would like to think instead of simply rejecting it for all the "Aristotelian elements" that are missing, perhaps he might join film critic Roger Ebert in ironically enjoying Nolan's labyrinthine narrative with comments similar to Ebert's:

Like the hero of the film, the viewer of INCEPTION is adrift in time and experience. We can never even be quite sure what the relationship between dream time and real time is. The hero explains that you can never remember the beginning of a dream, and that dreams that seem to cover hours may only last a short time. Yes, but you don't know that while you are dreaming. And what if you are inside another man's dream? How does your dream time synch with us? What do you really know? (Ebert, 2010)

In all fairness to Aristotle, in fact, we should agree with the popular screenwriting workshop teacher Robert McKee that, much of the clarity Aristophanes offered in The Poetics including, "dividing dramas according to the value charge of their ending verses their story design" (p. 79) has been lost as more and more genres with unclear structures have appeared. McKee observes that Johann von Goethe listed seven genres or types of dramatic structure, Johann von Schiller claimed there were more "but couldn't name them" (p. 79), and Georges Polti listed 36 dramatic situations. And McKee himself goes on to list 25 genres, ranging from Romance, Crime, Comedy and Western, to Maturation Plot, Disillusionment Plot, Education Plot and Punitive Plot (pp. 80-86).

And as we move towards "The End" of this essay, what resolution or catharsis can we offer on Aristotle, Hollywood's standard narratives and alternatives to both? I believe that Nougmanov's comments are helpful for in many areas of life, it's important to know the "rules", laws, traditions, and then to feel free to use, bend, alter, revise, or abandon them according to the spirit of the story and characters you wish to create. Even in a solidly Hollywood production such as Michael Curtiz's Casablanca (1942), the famous last line, "Louis, I think this is the beginning of a beautiful friendship", wasn't added until three weeks after the finishing of shooting the film. Does the line change the "catharsis" of the film which is Rick (Humphrey Bogart) choosing not to fly away with his true love Ilsa (Ingrid Bergman) as he takes the "higher road" in love by urging her to return to her husband Victor Laszlo (Paul Henreid), an important resistance fighter against the Nazis? The technical answer is "no, no change in the resolution". But the tone of this last line opens up Rick's character even more to suggest that beyond the pain of "letting go" of his true love Ilsa, he has the power of his own character to move on with his own life. 
I would conclude by saying the screenwriting team of Julius and Philip Epstein and Howard Koch, building on the stage play of Everybody Comes to Rick's, thus ended the story with an alternative resolution when audiences would have been expecting the Hollywood "happy ending" for a romance centered film. Casablanca can therefore be called both a character-centered screenplay in that we remember the characters and moments of them together more strongly than we remember a plot driven sense of story. And there is a beginning, middle, and end, even though In the spirit that Godard mentions, Casablanca starts with Act II and then goes to the beginning of the story as Ilsa walks in the door of Rick's café and brings us into a flashback of their beginnings before we return for the end of Act II and Act III. Moral of this tale? You can have your Aristotle and your own creativity as well!

\section{References}

Aristotle (1947). Aristotle on the art of poetry. Ithaca, NY: Cornell University Press.

Dorsch, T. S. (1978). Aristotle Horace Longinus: Classical literary criticism. New York: Penguin Books.

Ebert, R. (2010). Inception: Dreams on top of dreams inside dreams. Retrieved from http://www.Rogerebert.com

Egri, L. (1960). The art of dramatic writing. New York: Simon \& Schuster.

Field, S. (1982). Screenplay: The foundations of screenwriting. New York: Dell.

Horton, A. (1997). The films of Theo Angelopoulos: A cinema of contemplation. Princeton: Princeton University Press.

Horton, A. (1999). Writing the character centered screenplay (2nd ed.). Berkeley: University of California Press.

Horton, A. (2004). Screenwriting for a global market. Berkeley: University of California Press.

Hunter, L. (1993). Lew Hunter's screenwriting 434. New York: Penguin Group.

McKee, R. (1997). Story: Substance, structure, style and the principles of screenwriting. New York: HarperCollins.

Seger, L. (1990). Creating unforgettable characters. New York: An Owl Book.

Thompson, K. (1999). Storytelling in the New Hollywood. Cambridge, Mass: Harvard University Press.

Truby, J. (2007). The anatomy of story: 22 steps to becoming a master storyteller. New York: Faber and Faber.

Vogler, C. (2007). The writer's journey: Mythic structure for writers. Studio City, CA: Michael Wise Productions. 